\title{
Rabbits generated from fibroblasts through nuclear transfer
}

\author{
Shangang $\mathrm{Li}^{1}$, Xuejin Chen ${ }^{1}$, Zhenfu Fang ${ }^{1}$, Jianjun Shi ${ }^{2}$ and Hui Z Sheng ${ }^{1,2}$ \\ ${ }^{1}$ Center for Developmental Biology, Xinhua Hospital, Shanghai Jiao Tong University, School of Medicine and \\ ${ }^{2}$ Laboratory of Stem Cell Biology, Institute of Biochemistry and Cell Biology, Shanghai Institutes for Biological \\ Sciences, Chinese Academy of Sciences, Shanghai, 200092, P. R. China
}

Correspondence should be addressed to Hui Z Sheng; Email: hzsheng2003@yahoo.com

\begin{abstract}
Somatic cell nuclear transfer offers new opportunities for genetic engineering and genome preservation in mammalian animal species. We show that, in addition to cumulus cells, cultured adult rabbit fibroblasts are also capable of supporting full-term development after nuclear transfer. Nuclear transfer embryos constructed using serum-starved fibroblasts showed a significantly higher developmental rate than non-starved fibroblasts through preimplantation stages. A total of $\mathbf{4 6 7}$ nuclear transfer embryos were transferred into the oviducts of pseudo pregnant mothers. Eight of the 20 surrogate rabbits carried the pregnancy to term and five of them gave birth naturally to a total of nine rabbits. However, all of the offspring died before postnatal day 10. A Caesarean section was performed on three surrogates, giving birth to a total of five rabbits, three of them survived and grew into healthy adults. DNA analyses confirmed that these rabbits were genetically identical to the donor male rabbit. The present study demonstrates that rabbits can be cloned from adult fibroblasts after culture.
\end{abstract}

Reproduction (2006) 131 1085-1090

\section{Introduction}

Somatic cell nuclear transfer (SCNT) offers new opportunities for genetic engineering and genome preservation in mammalian animal species. Although overall cloning efficiency is low, rapid progress has been made to improve the technology. So far, SCNT has succeeded in generating live animals in many species, including sheep (Schnieke et al. 1997, Wilmut et al. 1997), cattle (Cibelli et al. 1998, Kato et al. 1998), mice (Wakayama et al. 1998), goats (Baguisi et al. 1999), pigs (Betthauser et al. 2000, Onishi et al. 2000, Polejaeva et al. 2000), cats (Shin et al. 2002), mules (Woods et al. 2003), horses (Galli et al. 2003), rats (Zhou et al. 2003) and dogs (Lee et al. 2005).

The relatively large body size of rabbits makes them the preferred animal species for a variety of fields, including pulmonary and cardiovascular research, as well as drug screenings, toxicity tests and metabolic studies that require frequent blood sampling. Given their frequent use in research, the creation of genetically modified rabbit lines is highly desirable. It has been previously demonstrated in bovines (Cibelli et al. 1998) and pigs (Lai et al. 2002, Ramsoondar et al. 2003) that fibroblasts can be genetically modified and used as nuclear donors to produce animals with specific genetic traits. Theoretically, it should then also be feasible to generate mutant rabbit lines by modifying the genome of rabbit fibroblasts by homologous recombination.
Rabbits were cloned from blastomeres many years ago (Stice \& Robl 1988). The development of SCNT technology in rabbits has been the focus of much recent research (Mitalipov et al. 1999, Dinnyes et al. 2001, Inoue et al. 2002, Yin et al. 2002) and only female rabbits have been successfully cloned from freshly isolated cumulus cells using modified oocyte activation and embryo transfer protocols (Chesne et al. 2002). In the current study, we demonstrate the feasibility of an alternative SCNT protocol to clone rabbits from adult fibroblasts after culture. This may facilitate genetic engineering and genome preservation in rabbits.

\section{Materials and Methods}

Unless otherwise noted, all media used were purchased from Gibco Invitrogen. Animal care and the SCNT protocol were approved by the Ethics Committee of Shanghai Jiao Tong University, School of Medicine.

\section{Oocyte collection}

Mature White New Zealand female rabbits (approximately $3.5 \mathrm{~kg}$ and more than 6 months old) were superovulated by intramuscular injection of $150 \mathrm{IU}$ of eCG (equine Chorionic Gonadotropin, Huafu high-tech Co. Ltd, Tianjin, China) followed, $96 \mathrm{~h}$ later, by an intravenous 
injection of 100 IU hCG (human Chorionic Gonadotropin, Zhongbao Co. Ltd, Tianjin, China) to induce ovulation. The ovulated oocytes were recovered at $14 \mathrm{~h}$ post hCG injection by flushing the oviducts with pre-warmed RD medium (50\% RMPI 1640 and 50\% DMEM) (Carney \& Foote 1991) supplemented with $10 \%(\mathrm{v} / \mathrm{v})$ fetal cattle serum (FCS, Hyclone Co.) and $10 \mathrm{mmol}$ Hepes/l (Hepes balanced RD, hRD). Cumulus cells were removed by exposure to $100 \mathrm{IU}$ hyaluronidase/ml (Sigma chemical Co.) in hRD medium for $10 \mathrm{~min}$ and then pipetted through a fine pipette. Denuded oocytes were washed six times and incubated $\left(38^{\circ} \mathrm{C}\right)$ in RD medium supplemented with $10 \%$ FCS, $2 \mathrm{mmol}$ glutamine/l, $223 \mu \mathrm{mol}$ sodium pyruvate/l and $100 \mu \mathrm{mol}$ MEM non-essential amino acids/l (modified $\mathrm{RD}, \mathrm{mRD}$ ) and maintained in a humidified atmosphere $\left(5 \% \mathrm{CO}_{2}\right)$ until use.

\section{Preparation of nuclear donors}

Fibroblasts were collected through ear-skin biopsy of an adult New Zealand male rabbit as previously described (Dinnyes et al. 2001). The skin piece was washed several times in Dulbecco PBS, cut into $1 \mathrm{~mm}$ cubes and cultured as explants in DMEM supplemented with $20 \%$ FCS $\left(37^{\circ} \mathrm{C}, 5 \% \mathrm{CO}_{2}\right)$. Fibroblasts developed from explants within approximately 10 days. Cells were then digested with $0.05 \%$ trypsin-EDTA, passed to a new dish (passage 1) then expanded further in DMEM with $10 \%$ FCS for up to the 13 passages. Some fibroblasts used in the study were frozen in liquid nitrogen. Cells from passages 6 to 13, either fresh or thawed, were used as nuclear donors in the cloning experiments.

Before nuclear transfer, $1.5 \times 10^{5}$ fibroblasts were plated and cultured until cells reached confluency (CC group, confluent culture). Cells were subsequently digested with trypsin and used as nuclear donors. The medium was replaced with DMEM supplemented with $0.5 \%$ FCS, $2-5$ days before cells were used as nuclear donors (starved cells, SC group). Nuclear donor fibroblasts were routinely resuspended in DMEM with $10 \%$ FCS. Cells small in size and with a smooth surface were selected for the nuclear transfer experiments.

\section{Nuclear transfer}

A total of 40-80 oocytes were obtained from three rabbits for each nuclear transfer experiment. Oocytes with a normal looking metaphase plate and with the first polar body under the zona pellucida were selected for nuclear transfer. Less than $5 \%$ of freshly collected oocytes showed an abnormal size (e.g. out diameter $>200 \mu \mathrm{m}$ ) or color (e.g. opaque in the center). These oocytes were considered unhealthy and discarded. Oocytes were incubated $\left(38^{\circ} \mathrm{C}, 10 \mathrm{~min}\right)$ with $\mathrm{hRD}$ supplemented with $7.5 \mu$ g cytochalasin B/ml (Sigma Chemical Co.) before enucleation. The metaphase plate and polar body was visualized with an inverted microscope equipped with a Spindleview system (Cambridge Research \& Instrumentation Inc.) and was removed with an enucleation pipette (18-22 $\mu \mathrm{m}$, out diameter; 15-20 oocytes were enucleated within $10 \mathrm{~min}$ ). The microscope work plate was maintained at $37^{\circ} \mathrm{C}$.

Single nuclear donor cells were inserted into the perivitelline space of enucleated oocytes. The oocytefibroblast units were manually oriented in a $1 \mathrm{~mm}$ gap chamber of an Electro Cell Manipulator (BTX 830, San Diego, CA) in $0.3 \mathrm{~mol}$ Sorbitol/l solution containing $0.1 \mathrm{mmol}$ calcium acetate/l, $0.5 \mathrm{mmol}$ magnesium acetate $/ \mathrm{l}$ and $1 \mathrm{mg} \mathrm{BSA} / \mathrm{ml}$ (Sigma Chemical Co.). Oocyte-fibroblast units were subjected to three $20 \mu \mathrm{sec}$ DC pulses of $3.0 \mathrm{KV} / \mathrm{cm}$ and were then incubated with $\mathrm{mRD}\left(80 \mathrm{~min}, 38^{\circ} \mathrm{C}\right)$. To activate the nuclear transfer embryos (nt-embryo) a second set of electropulses was delivered at $16.5 \mathrm{~h}$ to $18 \mathrm{~h}$ after hCG injection, followed by incubation $\left(1 \mathrm{~h}, 38^{\circ} \mathrm{C}\right)$ with mRD containing $5 \mu \mathrm{g}$ cycloheximide/ml (Sigma Chemical Co.) and $2 \mathrm{mmol}$ 6-dimethylaminopurine/l (Sigma Chemical Co.) as previously described (Chesne et al. 2002). After chemical activation, nt-embryos were incubated with $\mathrm{mRD}$ for $2 \mathrm{~h}$ followed by $50 \mu \mathrm{l}$ of upgraded B2 medium (Laboratoire C.C.D, Paris, France) supplemented with $2.5 \%$ FCS. The culture was maintained under mineral oil (Sigma-Aldrich, Inc.) at $38{ }^{\circ} \mathrm{C}$ in a humidified atmosphere of $5 \% \mathrm{CO}_{2}$.

\section{Embryo transfer}

Pseudopregnant rabbits received $80 \mathrm{IU}$ hCG with a $24 \mathrm{~h}$ delay in comparison to the protocol used for oocyte donor rabbits. 8-15 nt-embryos at 2- to 8-cell stage were transferred, through the infundibulum, into each oviduct of the pseudopregnant rabbits.

\section{Microsatellite marker analysis}

The nuclear donor rabbit, three cloned progenies and two surrogated mothers were genotyped using the following five primer sets: 5L1C3 (AF421908), ELAMB (M91055), ASICG (AY284844), 6L1F10 (AF421916) and 19L1A4 (AF421948) (van Haeringen et al. 1996, Korstanje et al. 2003). Genomic DNA was extracted from the blood of all the rabbits.

\section{Statistical analysis}

The fusion and development of activated nt-embryos to blastocyst stage was evaluated and data from different treatments were compared with chi-square analysis.

\section{Results}

To prepare nt-embryo, a fibroblast was inserted into the perivitelline space and fused to the enucleated oocyte. As shown in Table 1, a total of 178 and 240 
Table 1 Pre-implantation stage development of nt-embryos resulting from donor cells from serum-starved and none-starved groups.

\begin{tabular}{lcccc}
\hline Donor cell treatment & Oocytes used & No. $(\%)$ fused nt-embryos & No. (\%) cleaved nt-embryos & No. (\%) blastocysts \\
\hline $\mathrm{CC}^{\mathrm{a}}$ & 178 & $115(66)$ & $75(65)^{\mathrm{c}}$ & $24(21)^{\mathrm{e}}$ \\
$\mathrm{SC}^{\mathrm{b}}$ & 240 & $173(72)$ & $135(78)^{\mathrm{d}}$ & $77(45)^{\mathrm{f}}$ \\
\hline
\end{tabular}

${ }^{\mathrm{a} C C}$ : confluent cells, none-starved group.

${ }^{\mathrm{b}} \mathrm{SC}$ : serum starved cells.

${ }^{\mathrm{c}-\mathrm{f}}$ Chi-square analyses demonstrating statistical difference between $\mathrm{c}$ and $\mathrm{d}(P<0.05)$ and e and $\mathrm{f}(P<0.01)$.

reconstructed couplets were produced using fibroblasts from the CC group and the SC group respectively. Thirty minutes after electrofusion, 65\% (115/178) of couplets from the CC group and $72 \%(173 / 240)$ of couplets from the SC group had fused successfully. The chromatin of the donor cells became condensed to form chromosomes approximately $1 \mathrm{~h}$ after electrofusion (Fig. 1A).

The fused nt-embryos were activated by a second set of electropulses $80 \mathrm{~min}$ after fusion and subsequent incubation in activation medium for an hour. Pronuclearlike structures appeared (Fig. 1B) at $2 \mathrm{~h}$ after chemical activation, in $67 \%$ (46/69) of nt-embryos in the CC group and $73 \%(49 / 67)$ of nt-embryos in the SC group. Individual nt-embryos displayed one, two or more pronuclear-like nuclei. Most nt-embryos entered the 2-cell stage 9-14 $\mathrm{h}$ after chemical activation, the 4-cell stage within 12-18 h, the 8-cell stage within $20-24 \mathrm{~h}$ (Fig. 1C), the morula within $48 \mathrm{~h}$ (Fig. 1D) and the blastocyst stage within $72 \mathrm{~h}$ (Fig. 1E). Some blastocysts hatched out entirely from the zona pellucida approximately $120 \mathrm{~h}$ after activation (Fig. 1F).

The CC and SC groups were compared for performance at each of the pre-implantation stages. As shown in Table 1, a higher percentage of nt-embryos in the SC group entered cleavage (SC:CC $=78 \%: 65 \%, P<0.05$ ) and a significantly higher percentage of nt-embryos in the SC group developed into blastocyst (SC:CC = $45 \%: 21 \%, P<0.01$ ).
Given that the SC group produced nt-embryos with better developmental performance, serum-starved cells were used as nuclear donors in subsequent experiments. As shown in Table 2, of 675 nt-embryos obtained from 945 reconstructed couplets, 494 cleaved $(73 \%$, 494/ 675). A total of 467 nt-embryos at 2-8-cell stage were transferred into the oviducts of 20 pseudopregnant recipients, of which eight carried the pregnancy to term $(40 \%, 8 / 20)$. As shown in Table 3, five of the eight surrogate rabbits gave natural birth to nine progenies. All of them died within 10 days of birth. The high death rate appeared to be related to two reasons. First, a proportion of rabbits borne after prolonged gestation experienced dyspnea, the prolonged gestation might have prevented normal postnatal development and function of the organs. Secondly, several surrogate mothers carrying cloned babies had no colostrums in time when the babies were born. The babies tended to die if they did not get milk within $6 \mathrm{~h}$ after birth.

In an attempt to improve survival rates, we performed Caesarean sections on the other three pregnant surrogate rabbits at 30 days after embryo transfer and helped the newborn babies to get milk from other mothers. Of the five progenies obtained, four were alive at birth. Although one died on the same day, the other three (one borne on July 1, 2005; two borne on July 8, 2005) lived and grew into healthy male adults (Table 3 and Fig. 2A). The remaining three live rabbits were 7 months
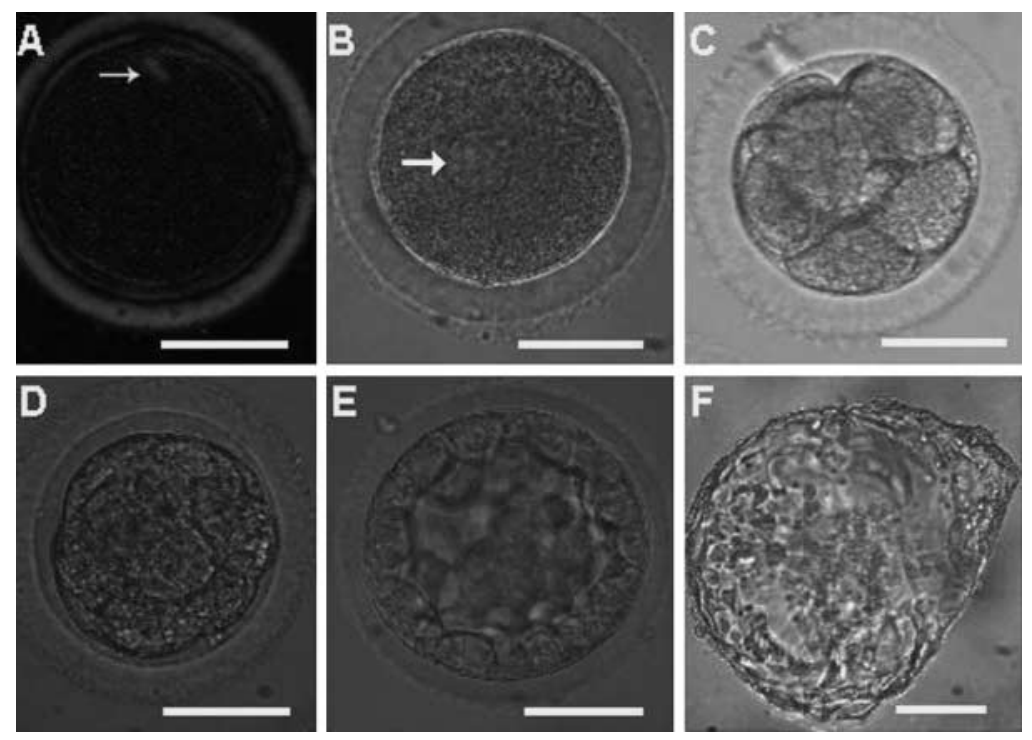

Figure $1 \mathrm{Nt-embryos}$ in pre-implantation stages. (A) Condensed chromosomes (arrow) in the nt-embryo $(1 \mathrm{~h}$ after fusion). (B) The pronuclear-like structure (arrow) in the nt-embryo ( $2 \mathrm{~h}$ after activation). ( $\mathrm{C}$ to $\mathrm{E}$ ) Nt-embryos at the 8-cell, the morula, and the blastocyst stage respectively. (F) A hatched blastocyst. Bar $=50 \mu \mathrm{m}$. 
Table 2 A summary in development of nuclear transfer embryos in vivo.

\begin{tabular}{lc}
\hline Sample size & Developmental rate \\
\hline No. reconstructed couplets & 945 \\
No. fused couplets (\% from reconstructed) & $675(71)$ \\
No. cleaved embryos (\% from fused) & $494(73)$ \\
No. transferred embryos & 467 \\
No. recipient mothers & 20 \\
No. recipients delivering (\% of total recipients) & $8(40)$ \\
No. full-term fetus (\% from transferred embryos) & $14(3.0)$ \\
Birth weight (g) & $55 \pm 21(n=12)$ \\
\hline
\end{tabular}

Table 3 Better survival of cloned rabbits by Caesarean section.

\begin{tabular}{lcc}
\hline Type of birth way & Natural birth & Caesarean \\
\hline No. surrogate rabbits & 5 & 3 \\
No. full-term fetus & 9 & 5 \\
No. alive fetus & 8 & 4 \\
No. alive at weaning & 0 & 3 \\
\hline
\end{tabular}

old when this paper was written. One of the cloned rabbits was mated to a conventional female rabbit and the mating produced eight healthy baby rabbits. This result demonstrated that the cloned rabbit was fertile. Microsatellite DNA analysis confirmed that all three cloned rabbits were genetically identical to the nuclear donor male rabbit (Fig. 3 and Fig. 2B).

The body weights of cloned rabbits were in a normal range on average $(55 \pm 21 \mathrm{~g}, n=12)$ as compared to normal newborn rabbits $(56.1 \pm 5.1 \mathrm{~g}, n=43)$, although cloned rabbits displayed more variations. For example, one baby rabbit born at 35 days reached $93 \mathrm{~g}$ and another by Caesarean section at 30 days weighed only $20 \mathrm{~g}$.

Primary cultures have been suggested to have less homogenous cell types initially (Kubota et al. 2000). Because of this, we utilized cells after at least six passages, when populations grew more vigorous and appeared more homogenous in morphology. We obtained $14(3 \%, 14 / 467)$ (Table 2$)$ full-term development rabbits using fibroblasts from passages 6 to 13, and
12 were from frozen stored donor cells. The three lived rabbits were cloned from fibroblasts which have been passaged 11 and 12 times. These results demonstrate that the cell culture protocol utilized was suitable for growing nuclear donor cells and that the frozen-thawed processes did not cause apparent damage in the developmental capacity of fibroblasts.

\section{Discussion}

In the current study, we demonstrate that adult rabbit fibroblasts can be cultured, expanded and frozen without losing their ability to support the development of nt-embryos, a technology which may potentially be used to modify fibroblast genome by homologous recombination so as to generate genetically altered cloned rabbits.

After the birth of Dolly, it became apparent that somatic cells at the G0/G1 phase could potentially be better nuclear donors (Wilmut et al. 1997). Cumulus cells have been used successfully in many animal cloning experiments and $90 \%$ of the freshly isolated mouse cumulus cells are naturally in the G0/G1 stage (Schuetz et al. 1996, Wakayama et al. 1998). Since cumulus cells can only be isolated from female donors to produce female progenies, fibroblasts can be used as an alternative source of nuclear donors and without limitations to age, sex or physiological state.

Serum starvation is an effective way to induce cells into an inactive G0/G1 cell stage. Another method is to maintain confluent cell cultures for a prolonged time period (Boquest et al. 1999, Dinnyes et al. 2001). In our experiments we obtained higher rates of blastocysts when serum-starved cells were used as donors for nuclear transfer, compared to the rates obtained from nuclear transfer utilizing confluent cells.

In the current study, we collected oocytes $14 \mathrm{~h}$ after hCG injection and prolonged the time between fusion and activation to $80 \mathrm{~min}$. This protocol, which may have permitted a longer interaction time between the ooplasm and the nucleus, led to successful blastocyst
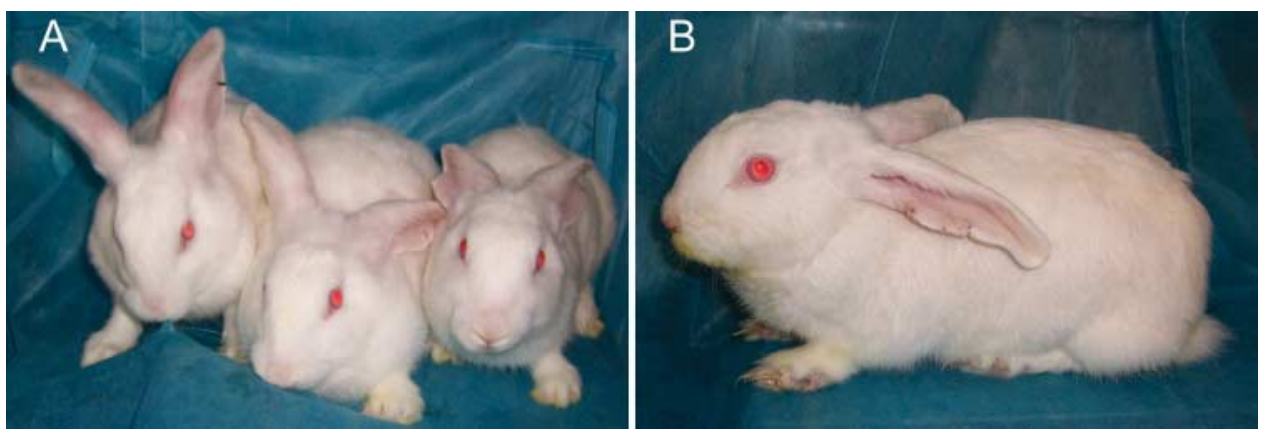

Figure 2 Rabbits cloned from adult fibroblasts. (A) Three cloned rabbits (5 month old) resulting from nuclear transfer. (B) The male rabbit whose fibroblasts were used as the nuclear donors in this study. 


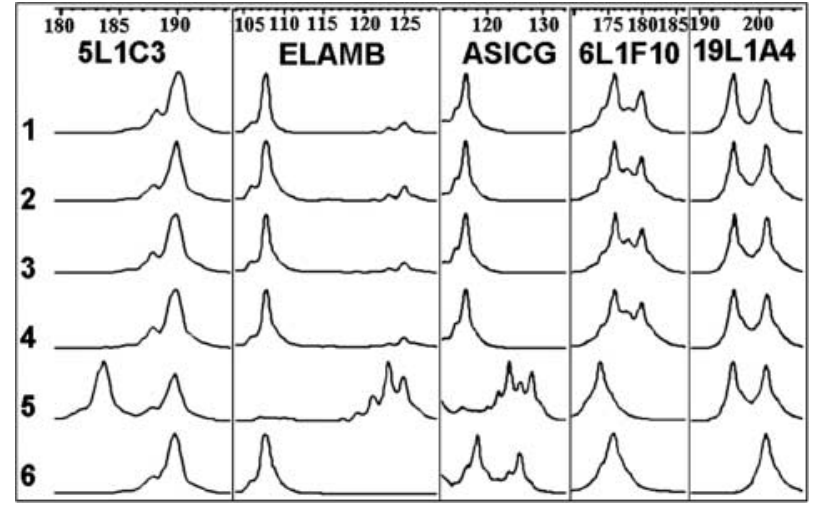

Figure 3 Microsatellite analyses of rabbit genome. 1, nuclear donor rabbit; 2-4, cloned rabbits; 5 and 6, surrogate rabbits. 5L1C3, ELAMB, ASICG, 6L1F10 and 19L1A4 are the five PCR primer sets used to detect DNA polymorphism in rabbits. The numbers at the top of the figure indicate the sizes of base pairs.

development consistently, providing a variation to that of Chesne et al., who cloned rabbits with oocytes collected $16 \mathrm{~h}$ after hCG injection (Chesne et al. 2002). Additionally, we utilized a "Spindle View" apparatus to view the oocyte metaphase plate, resulting in better enucleation efficiency.

Chesne et al. (2002) found that the pre-implantation development of nt-embryos was delayed by approximately one day compared to normal embryos. Therefore they performed embryo transfer at the 2 -4-cell stage using asynchronous recipients mated to vasectomized males $22 \mathrm{~h}$ after the donor females. Following the same idea, we transferred nt-embryos at the 2-8-cell stage using asynchronous recipients which were induced ovulation $24 \mathrm{~h}$ after the donor females were induced. Eight out of 20 recipients gave birth to $14(3 \%)$ fully developed progenies, of which 12 were alive at birth. These results confirmed that an asynchronous embryo transfer scheme is important for cloning rabbits.

Although a high percentage of the nt-embryos developed to the blastocyst stage in in vitro culture, rabbit had a narrow window for implantation in vivo that often resulted in low implantation rates of nt-embryos. In addition, prolonged gestation and inappropriate feeding immediately after birth can lead to death of the newborn. As described in this paper, Caesarean section, in combination with appropriate care and feeding of the infants, improved the survival rate of cloned rabbits to $60 \%$ (3 out of 5 ). These data emphasize the importance in caring for the cloned infant rabbits that, like other cloned species, tend to carry physiological defects.

In summary, the present study has demonstrated that rabbits can be cloned from long-term cultured adult fibroblasts. This method may facilitate genome preservation and genetic engineering in rabbits.

\section{Acknowledgements}

We thank Wanli Li, Youming Zhu, Wenqin Ying, and Fengying Li for excellent technical assistance and animal care.

The study was supported by grants from National Basic Research Program of China (973 Program) (No. 001CB509903, 001CB509904), Hi-Tech Research and Development Program of China (973 Program) (No. 2001AA216121, 2004AA205010), National Natural Science Foundation of China (No. 30040003), Science and Technology Committee of Shanghai Municipality (No. 99DJ14002, 00DJ1 4033, 01DJ14003, 03DJ14017), Chinese Academy of Science (No. KSCX-2-3-08), Shanghai Municipal Education Commission and Shanghai Jiao Tong University, School of Medicine.

\section{References}

Baguisi A, Behboodi E, Melican DT, Pollock JS, Destrempes MM, Cammuso C, Williams JL, Nims SD, Porter CA, Midura P, Palacios MJ, Ayres SL, Denniston RS, Hayes ML, Ziomek CA, Meade HM, Godke RA, Gavin WG, Overstrom EW \& Echelard Y 1999 Production of goats by somatic cell nuclear transfer. Nature Biotechnology 17 456-461.

Betthauser J, Forsberg E, Augenstein M, Childs L, Eilertsen K, Enos J, Forsythe T, Golueke P, Jurgella G, Koppang R, Lesmeister T, Mallon K, Mell G, Misica P, Pace M, Pfister-Genskow M, Strelchenko N, Voelker G, Watt S, Thompson S \& Bishop M 2000 Production of cloned pigs from in vitro systems. Nature Biotechnology 18 1055-1059.

Boquest AC, Day BN \& Prather RS 1999 Flow cytometric cell cycle analysis of cultured porcine fetal fibroblast cells. Biology of Reproduction 60 1013-1019.

Carney EW \& Foote RH 1991 Improved development of rabbit one-cell embryos to the hatching blastocyst stage by culture in a defined, protein-free culture medium. Journal of Reproduction and Fertility 91 113-123.

Chesne P, Adenot PG, Viglietta C, Baratte M, Boulanger L \& Renard JP 2002 Cloned rabbits produced by nuclear transfer from adult somatic cells. Nature Biotechnology 20 366-369.

Cibelli JB, Stice SL, Golueke PJ, Kane JJ, Jerry J, Blackwell C, Ponce de Leon FA \& Robl JM 1998 Cloned transgenic calves produced from nonquiescent fetal fibroblasts. Science 280 1256-1258.

Dinnyes A, Dai Y, Barber M, Liu L, Xu J, Zhou P \& Yang X 2001 Development of cloned embryos from adult rabbit fibroblasts: effect of activation treatment and donor cell preparation. Biology of Reproduction 64 257-263.

Galli C, Lagutina I, Crotti G, Colleoni S, Turini P, Ponderato N, Duchi R \& Lazzari G 2003 Pregnancy: a cloned horse born to its dam twin. Nature $\mathbf{4 2 4} 635$.

Inoue K, Ogonuki N, Yamamoto Y, Noguchi Y, Takeiri S, Nakata K, Miki H, Kurome M, Nagashima H \& Ogura A 2002 Improved postimplantation development of rabbit nuclear transfer embryos by activation with inositol 1,4,5-trisphosphate. Cloning and Stem Cells 4 311-317.

Kato Y, Tani T, Sotomaru Y, Kurokawa K, Kato J, Doguchi H, Yasue H \& Tsunoda Y 1998 Eight calves cloned from somatic cells of a single adult. Science 282 2095-2098.

Korstanje R, Gillissen GF, Versteeg SA, van Oost BA, Bosma AA, RogelGaillard C, van Zutphen LF \& van Lith HA 2003 Mapping of rabbit microsatellite markers using chromosome-specific libraries. The Journal of Heredity 94 161-169.

Kubota C, Yamakuchi H, Todoroki J, Mizoshita K, Tabara N, Barber M \& Yang X 2000 Six cloned calves produced from adult fibroblast cells after long-term culture. Proceedings of the National Academy of Sciences USA 97 990-995.

Lai L, Kolber-Simonds D, Park KW, Cheong HT, Greenstein JL, Im GS, Samuel M, Bonk A, Rieke A, Day BN, Murphy CN, Carter DB, 
Hawley RJ \& Prather RS 2002 Production of alpha-1,3-galactosyltransferase knockout pigs by nuclear transfer cloning. Science $\mathbf{2 9 5}$ 1089-1092.

Lee BC, Kim MK, Jang G, Oh HJ, Yuda F, Kim HJ, Shamim MH, Kim JJ, Kang SK, Schatten G \& Hwang WS 2005 Dogs cloned from adult somatic cells. Nature 436641.

Mitalipov SM, White KL, Farrar VR, Morrey J \& Reed WA 1999 Development of nuclear transfer and parthenogenetic rabbit embryos activated with inositol 1,4,5-triphosphate. Biology of Reproduction 60 821-827.

Onishi A, Iwamoto M, Akita T, Mikawa S, Takeda K, Awata T, Hanada H \& Perry AC 2000 Pig cloning by microinjection of fetal fibroblast nuclei. Science 289 1188-1190.

Polejaeva IA, Chen SH, Vaught TD, Page RL, Mullins J, Ball S, Dai Y, Boone J, Walker S, Ayares DL, Colman A \& Campbell KH 2000 Cloned pigs produced by nuclear transfer from adult somatic cells. Nature 407 86-90.

Ramsoondar JJ, Machaty Z, Costa C, Williams BL, Fodor WL \& Bondioli KR 2003 Production of alpha 1,3-Galactosyltransferaseknockout cloned pigs expressing human alpha 1,2-fucosylosyltransferase. Biology of Reproduction 69 437-445.

Schnieke AE, Kind AJ, Ritchie WA, Mycock K, Scott AR, Ritchie M, Wilmut I, Colman A \& Campbell KH 1997 Human factor IX transgenic sheep produced by transfer of nuclei from transfected fetal fibroblast. Science $\mathbf{2 7 8} 2130-2133$.

Schuetz AW, Whittingham DG \& Snowden R 1996 Alterations in the cell cycle of mouse cumulus granulosa cells during expansion and mucification in vivo and in vitro. Reproduction, Fertility, and Development 8 935-943.

Shin T, Kraemer D, Pryor J, Liu L, Rugila J, Howe L, Buck S, Murphy K, Lyons L \& Westhusin M 2002 A cat cloned by nuclear transplantation. Nature $\mathbf{4 1 5} 859$.
Stice SL \& Robl JM 1988 Nuclear programming in nuclear transplant rabbit embryos. Biology of Reproduction 39 657-664.

van Haeringen WA, den Bieman M, van Zutphen LF \& van Lith HA 1996 Polymorphic microsatellite DNA markers in the rabbit (Oryctolagus cuniculus). Journal of Experimental Animal Science 38 49-57.

Wakayama T, Perry AC, Zuccotti M, Johnson KR \& Yanagimachi $R$ 1998 Full-term development of mice from enucleated oocytes injected with cumulus cell nuclei. Nature 394 369-374.

Wilmut I, Schnieke AE, McWhir J, Kind AJ \& Campbell KH 1997 Viable offspring derived from fetal and adult mammalian cells. Nature 385 810-813.

Woods GL, White KL, Vanderwall DK, Li GP, Aston KI, Bunch TD, Meerdo LN \& Pate BJ 2003 A mule cloned from fetal cells by nuclear transfer. Science 3011063.

Yin XJ, Kato Y \& Tsunoda Y 2002 Effect of enucleation procedures and maturation conditions on the development of nuclear-transferred rabbit oocytes receiving male fibroblast cells. Reproduction 124 $41-47$.

Zhou Q, Renard JP, Le Friec G, Brochard V, Beaujean N, Cherifi Y, Fraichard A \& Cozzi J 2003 Generation of fertile cloned rats by regulating oocyte activation. Science 3021179.

Received 8 December 2005

First decision 16 January 2006

Revised manuscript received 21 February 2006

Accepted 27 February 2006 